\title{
ANALISIS PENGARUH TOTAL SERVICE QUALITY MANAGEMENT TERHADAP KEPUASAN PELANGGAN JASA TRANSPORTASI
}

\author{
Oleh : Ika Yurul Qamari \\ Pungki Afrizal Rahman \\ Fakultas Ekonomi \\ Universitas Muhammadiyah Yogyakarta
}

\begin{abstract}
This research was conducted to analyze the influence of Total Service Quality Management to the customers satisfaction (the customers in this research were the user servicing Persada Tour \& Travel of Yogyakarta agency) by using 5 dimensions of TSQM: physical quality dimension, supporting physical quality, company/institution quality, technical quality dimension, and interactive quality dimension.

The method used for data collecting was survey method by giving questionnaires to the respondents. The technique used to take the samples of the research was purposive sampling. In this research validity and reliability tests were conducted to ensure the validity and reliability of the research instruments. Data analyzed used in the research were multiple linear regression, $t$ test, and $F$ test.

The result of the research shows that there is an influence of Total Service Quality Management to the customers satisfaction on the dimensions of physical quality; supporting physical quality; company/institution quality, technical quality, and interactive quality dimension forward the business class train passengers, both partially and simultaneously of all dimension. The most influential dimensions to the customers satisfaction is the company/institution quality.
\end{abstract}

Keyword : Service Quality, Satisfaction 
FHDADUUAN

Ixduetr jasa menunjukkan pertumbuhan yong cepat dan dinamis. Hal ini dilihat dari banyaknya jumlah perusahaan yang bergerak pada sektor industri jasa serta banyaknya perusahaan baru yang ikut berkecimpung pada industri jasa, terutama pada sektor jasa transportasi. Transportasi dinilai hal yang sangat penting untuk menunjang kegiatan manusia, sehingga dapat memberikan keuntungan yang menjanjikan bagi perusahaan.

Persaingan perusahaan penyedia jasa layanan transportasi tidak hanya pada banyaknya jumlah alat transportasi semata, akan tetapi pada kualitas pelayanan yang diberikan oleh penyedia jasa layanan transportasi. Kualitas merupakan salah satu faktor utama yang menentukan pemilihan produk bagi konsumen. Memberikan kualitas pelayanan yang dapat menghasilkan kepuasan konsumen akan membentuk loyalitas konsumen yang diharapkan akan menggunakan jasa layanan transportasi yang diberikan perusahaan secara berkesinambungan.

Era globalisasi sekarang ini, konsumen memiliki keragaman selera dan kebutuhan akan pelayanan yang berkualitas. Konsumen tidak lagi mempermasalahkan dari mana dan siapa yang membuatnya. Bagi konsumen, hal yang lebih penting adalah pelayanan yang dapat memenuhi harapannya. Demi mendapatkan pelayanan seperti yang diharapkannya, konsumen rela mengeluarkan uang lebih banyak.

Manajemen operasional yang baik didukung skill dan semangat kerja karyawan yang tinggi merupakan hal penting dalam pencapaian keberhasilan perusahaan transportasi. Total Sevice Quality Management (TSQM) atau bisa disebut Total Quality Service (TQS) adalah komitmen yang tepat untuk mengoperasionalisasi konsep yang berfokus pada pelanggan, menetapkan standar kinerja jasa dan memelihara antusiasme pelanggan pada segala waktu dan pangsa pasar.

Jasa layanan transportasi darat sangat beragam, salah satunya adalah travel. Travel menjadi pilihan konsumen karena dianggap mempunyai pelayanan yang lebih baik dari layanan transportasi darat yang lain. Travel dapat menjemput dan mengantarkan konsumen sampai tempat tujuan konsumen. Kesuksesan perusahaan jasa sangat bergantung pada penilaian dari konsumen. Penilaian kinerja perusahaan travel dapat dilihat dari kualitas pelavanan yang diberikan perusahaan kepada konsumennya. Perusahaan yang menerapkan TSQM akan lebih memprioritaskan kualitas pelayanan yang akan memberikar kepuasan pada konsumen. Kepuasan yang didapat oleh konsumen diharapkan akan membentuk intensi progmian $\therefore$ b gonortasi secara berkesinamburgan

Perusahaan yang benasil dalam penanganan pelanggan, yang vinumnya disebut dengan TSQM, merupakan hal yang memelukan perhatian ekstra dari manajerren perusahaan. Hal itu dapat dilaksanakan dengan penerapan strategi monitoring atau pengendalian yang ketat terhadap kualitas produk (Total Quality Qontrol) disertai strategi-strategi khusus dari perusahaan yang mendukung terwujudnya produktivitas kerja yang tinggi dan pencapaian TSQM yang baik, selanjutnya dapat mewujudkan Total Quality Management (TQM).

Total Quality Control (IQC) merupakan hal yang penting dan bersifat harus untuk dilakukan di setiap perusahaan yang menginginkan produktivitas kerja yang tinggi dan hasil produk/jasa yang berkualitas. Seperti yang dikemukakan oleh Mulyadi (1998) bahwa, "kualitas produk menjadi tanggung jawab setiap orang di dalam organisasi, sejak dari manajemen puncak sampai dengan karyawan, dari fungsi dan inspeksi sampai dengan fungsi-fungsi lain dalam organisasi perusahaan, bahkan meluas sampai organisasi pemasok dan mitra bisnis". Langkahlangkah lain untuk mencapai visi/tujuan perusahaan dapat dilakukan dengan berbagai cara, semua itu tergantung bagaimana manajemen dapat mengolah dan memproses sumber daya yang ada dengan semaksimal mungkin.

Penelitian ini adalah replikasi dengan menguji pengaruh kualitas layanan terhadap kepuasan, menggunakan 5 dimensi mutu TQM dari Said Dj. (2004) yaitu: mutu fisik, pendukung mutu fisik, mutu perusahaan/lembaga, mutu teknikal, dan mutı interaktif sebagai alat ukur kualitas pelayanan. Lima dimensi mutu tersebut merupakan instrumen mutu TQM yang dapat digunakan menganalisis kualitas jasa transportasi.

\section{PENGERTIAN KUALITAS.}

Kualitas merupakan faktor utama yang menentukan suatu pemilihan produk bagi konsumen. Tujuan organisasi bisnis/jasa dapat tercapai apabila dapat memproduksi produk yang berkualitas dan dapat memuaskan konsumennya. Kepuasan konsumen dapat tercapai apabila produk yang diterimanya berkualitas dan sesuai dengan kebutuhan dan keinginannya. Berbagai derinisi kualitas menurut para ahli, adalah sebagai berikut:

a. Menurut Juran, kualitas adalah fitness for use (kesesuaian penggunaan). Alat untuk pemecahan masalah adalah statistical process control (SPC), yang berorientasi untuk memenuhi kebutuhan pelanggan. 
b. Kotler P. (1997), kualitas sebagai keseluruhan ciri dan karakteristik produk jasa yang mendukung kemampuan untuk memuaskan kebuturar. Defnisinya menekankan pada fokus pelanggan.

c. Deming (1992), kualitas sebagai perbaikan terus menerus. Ia mendasarkan pada peralatan statistik, dengan proses bottom-up. Deming tidak memasukkan biaya ketidakpuasan pelanggan, karena menurutnya biaya ini tidak dapat diukur. Strategi Deming adalah dengan proses untuk memecahkan masalah, memberikan kepada manajemen peralatan yang tepat.

d. Taguchi (1987), kualitas adalah loss to society, yang maksudnya apabila terjadi penyimpangan dari target, hal ini merupakan fungsi dari berkurangnya kualitas. Strategi Taguchi memfokuskan pada peningkatan efisiensi dalam desain eksperimental dan memberikan petunjuk spesifik untuk perbaikan dan pertimbangan biaya, khususnya pada industri jasa.

e. Crosby (1979), kualitas sebagai kesesuaian dengan persyaratan. Dia melakukan pendekatan pada transformasi budaya kualitas. Konsep zero defect, tingkat kesalahan nol merupakan tujuan dari kualitas yang mengarahkan tingkat kesalahan sekecil mungkin, bahkan sampai tidak terdapat kesalahan.

Definisi-definisi yang dikemukakan tersebut pada dasarnya mempunyai pengertian yang sama, yaitu menyangkut tingkat kesesuaian dengan persyaratan, sebagaimana diungkap Crosby (1979). Persyaratan disini adalah persyaratan konsumen, hal ini disebabkan karena tujuan perusahaan adalah untuk memenuhi kebutuhan konsumen demi mencapai kepuasan konsumen.

\section{KUALITAS JASA}

Sifat dasar jasa yang tidak berwujud (intangible) dan lebih merupakan proses yang dialami pelanggan secara subyektif, dimana produksi dan konsumsi berlargsung bersamaan, membuat kualitas jasa lebih sulit didefinisikan dan diukur bila dibanding dengan kualitas pada barang. Proses pembentukan kualitas jasa dipengaruhi oleh interaksi antara penyedia jasa dan konsumen. Pada dasarnya kualitas jasa yang diberikan penyedia jasa bertujuan untuk pemenuhan kebutuhan dan keinginan konsumen/pelanggan jasa tersebut.

Kualitas jasa adalah setiap tindakan atau perbuatan yang dapat ditawarkan oleh suatu pihak kepada pihak yang lain yang pada dasarnya bersifat intangible (tioak berwujud fisik) dan ticak menghasilkan kepemilikan sesuru, seperi disebutkan Kotler P., (2000) dalam fandy Tj, (2005). Kualitas jasa merupakan tingkat keunggulan (excellence) yang diharapkan dan pengendaiian atas keunggulan tersebut untuk memenuhi keinginan pelanggan. Dengan kata lain, terdapat dua faktor utama yang mempengaruhi kualitas iasa yaitu, jasa yang diharapkan (expected service) dan jasa yang dipersepsikan (perceived service). Jadi, baik dan buruknya kualitas jasa tergantung pada kemampuan penyedia jasa dalam memenuhi harapan pelanggannya secara konsisten.

\section{TOTAL QUALITY MANAGEMENT (TQM).}

Total Quality Management merupakan suatu pendekatan dalam menjalankan usaha yang mencoba untuk memaksimumkan daya saing organisasi melalui perbaikan terus-menerus atas produk, jasa, manusia, proses, dan lingkungannya (Fandy Tj. dan Anastasia D., 2000).

Dasar pemikiran pentingnya TQM merupakan hal yang sederhana, yaitu bahwa cara terbaik agar dapat bersaing dan unggul dalam persaingan global adalah dengan menghasilkan kualitas yang terbaik. Menghasilkan kualitas yang terbaik diperlukan upaya perbaikan berkesinambungan terhadap manusia, proses, dan lingkungan. Cara terbaik supaya dapat memperbaiki kemampuan komponen-komponen tersebut secara berkesinambungan adalah dengan menerapkan TQM.

Penerapan TQM dilakukan dengan cara bertahap, karena dipengaruhi oleh beberapa faktor, seperti budaya organisasi, team work, lingkungan, dan lainnya. Paradigma baru dalam TQM adalah strategi nilai pelanggan, perbaikan terus-menerus dan sistem organisasi. Strategi nilai pelanggan merupakan penawaran nilai kepada pelanggan meliputi karakteristik produk atribut, model penyerahan, servis dan lainnya dengan berfokus pada tecapainya kepuasan pelanggan. Perbaikan dapat dilakukan pada kualitas, pengukuran, positioning, stakeholder dan desain produk.

Penerapan TQM dalam suatu perusahaan dapat memberikan beberapa manfaat yang pada akhirnya dapat meningkatkan laba serta daya saing perusahaan yang bersangkutan. Dengan melakukan perbaikan kualitas secara terus-menerus maka perusahaan dapat meningkatkan laba perusahaan melalui dua jalur seperti ditunjukkan pada Gambar 1. 
Gambar 1.

Maniaat TQM

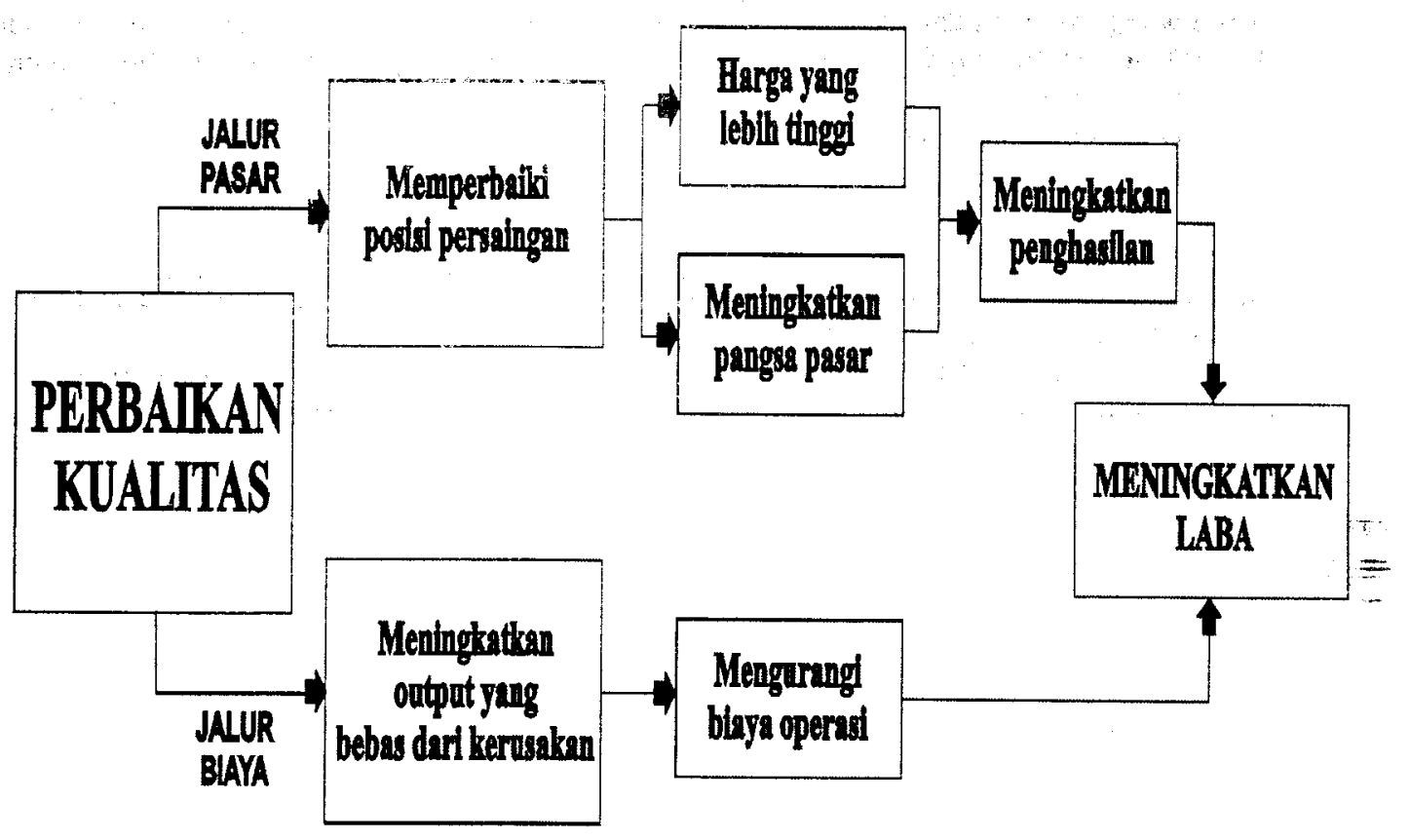

Sumber : Pall dalam Fandy Tj. dan Anastasia D., 2000.

Total Service Quality Management (TSQM). Total Service Quality Management atau bisa disebut Total Quality Service adalah komitmen yang tepat untuk mengoperasionalisasi konsep yang berfokus pada pelanggan, menetapkan standar kinerja jasa dan memelihara antusiasme pelanggan pada segala waktu dan pangsa pasar (Stamatis, 1996 dalam Munjiati M., 2003).

Total Service Quality Management (TSQM) merupakan konsep strategik dengan melibatkan manajer, pekerja dengan menggunakan metode kualitatif maupun kuantitatif untuk terusmenerus memperbaiki proses organisasi untuk memenuhi dan melampaui kebutuhan pelanggan. Total Servive Quality: Management (TSQM) merupakan deviasi dari Total Quality Management (TQM) dalam industri jasa, yang merupakan konsep tentang bagaimana menanamkan kualitas pelayanan pada setiap fase penyelenggaraan jasa yang melibatkan semua personil yang ada dalam organisasi. Lima fokus Total Service Quality. Management: (a) Customer focus, (b) Total involment, (c) Measurement, (d) Systematic support, (e) Continual Improve

\section{Pengukuran Kualitas Jasa}

Kualitas jasa dan kepuasan pelanggan mempunyai keterkaitan atau hubungan yang erat. Kualitas jasa sebagai sarana pengukuran baik tingkat jasa yang disalurkan selaras dengan harapan konsumen.
Penggunaan istilah jasa/pelayanan dalam penelitian ini mempunyai maksud dan tujuan yang sama yaitu untuk mengemukakan kualitas jasa atau pelayanan yang dirasakan oleh pelanggan. Penggunaan istilah jasa atau pelayanan dalam penelitian ini disesuaikan dengan kalimatnya.

Said Dj., (2004) pada riset jasa transportasinya di kapal Ferri, memaparkan kualitas pelayanan dan faktor-faktor yang menentukannya dengan mendefinisikan kualitas pelayanan sebagai derajat ketidakcocokan antara harapan normatif konsumen pada jasa pelayanan dan persepsi pelanggan yang diterima. Pengukuran kualitas pelayanan menggunakan riset empiris selanjutnya menghasilkan SERVQUAL, yakni suatu skala yang terdiri dari 40 item untuk mengukur pelayanan yang tercakup dalam 5 dimensi, yaitu

a. Mutu fisik $\left(\mathrm{X}_{1}\right)$, adalah mutu/kualitas dari segi fisik (bangunan) yang mampu mempengaruhi kepuasan pelanggan. Mutu fisik dari obyek penelitian ini yaitu; kondisi fisik pelabuhan, kondisi fisik dermaga, kondisi fisik kapal, kinerja para pejabat, ruang parkir kendaraan, ruang tunggu penumpang, tata ruang pelabuhan, jalan masuk dan keluar dari pintu kapal, kenyamanan dan kebersihan diatas kapal, kenyamanan dan kebersihan dipelabuhan, dan ukuran serta mutu tempat duduk penumpang di atas kapal.

b. Mutu pendukung fisik $\left(\mathrm{X}_{2}\right)$, adalah mutu kualitas yang mendukung kinerja/manfaat dari fasilitas fisik yang dapat mempengaruhi kepuasan pelanggan. Mutu 
pendukung fisik dari obyek penelitian ini yaitu; alat perlengkapan keselamatan, transport lanjutan, jalan masuk dan kelua: stasiun, ruang parkir kendaraan, ruang turggu, fasilitas didalam stasiun, fasilitas didalam pelabuhan, dan fasilitas umum.

c. Mutu perusahaan/lembaga $\left(X_{3}\right)$, adalah mutu/kualitas dari perusahaan/lembaga penyedia layanan, yang dapat mempengaruhi kepuasan pelanggan dan biasanya didasarkan pada kinerja operasional perusahaan. Mutu perusahaan/lembaga pada obyek penelitian ini yaitu; tepat waktu keberangkatan dari pelabuhan ketempat tujuan, tepat waktu kedatangan kapal dipelabuhan, tepat waktu dalam sistim bongkar muat barang dan penumpang, kemudahan mendapatkan tiket, dedikasi pejabat, bebas bahaya, perhitungan dan penyimpangan muatan, dan tanggung jawab perusahaan.

d. Mutu teknikal $\left(\mathrm{X}_{4}\right)$, adalah mutu/kualitas dari segi teknis dalam hal pelayanan yang dapat mempengaruhi kepuasan pelanggan. Mutu teknikal dari obyek penelitian ini yaitu; pengetahuan petugas/pejabat dalam bidang pelayanan, pengetahuan petugas/pejabat dalam bidang pelanggan, pengetahuan petugas/pejabat dalam bidang koordinasi kerja, pengetahuan petugas/pejabat dalam bidang kerjanya, kecepatan petugas/pejabat dalam bekerja dan ketangkasan petugas/pejabat dalam bekerja.

e. Mutu interaktif $\left(X_{5}\right)$ adalah mutu/kualitas yang dinilai dengan performa dan kualitas interaktif atau kemampuan berkomunikasi pihak perusahaan dengan pelanggan, dan hal itu dapat mempengaruhi kepuasan pelanggan tersebut. Mutu interaktif dalam obyek penelitian ini yaitu; memberikan informasi pada pelanggan, penanganan keluhan pelanggan, penanganan dalam kecelakaan, kejujuran petugas/pejabat dalam bekerja, keramahan petugas/pejabat dalam bekerja, mental petugas/pejabat dalam pelayanan, memecahkan masalah dengan cepat, koordinasi kerja petugas/pejabat dalam menangani masalah, memberikan perhatian kepada pelanggan, empati pada pelanggan, dan saling pengertian/toleransi.

\section{KEBÜTUHAN DAN KEPUASAN \\ PELANGGAN.}

Maksud menentukan kebutuhan pelanggan adalah untuk membentuk suatu daftar semua dimensi mutu yang penting dalam menguraikan barang atau jasa. Mengetahui dimensi mutu sangatlah penting, sehingga akan mengetahui bagaimana pelanggan mendefinisikan mutu barang atau jasa yang diterimanya. Hanya dengan memahami dimensi mutu, akan dapat mengembangkan ukuran untuk menilai dimensi mutu ini.

Meskipun ada beberapa dimensi mutu sturdar yang digeneralisasi (generalized) pada banyak jenis produk dan jasa, beberapa dimensi hanya akan berlaku pada jenis produk tertentu. Dimensi mutu berlaku untuk berbagai jenis organisasi penghasil jasa, meliputi keberadaan (avalilability), ketanggapan (responsiveness), menyenangkan (convenience), dan tepat waktu (time liness) (Kennedy and Young, 1989 dalam Supratno I., 2001). Sehingga sangatlah penting bagi setiap perusahaan untuk mengidentifikasi barang dan jasanya. Menganalisis barang dan jasa akan memberikan suatu gambaran yang komprehensif dari dimensi ini.

Supaya perusahaan dapat unggul atau bahkan hanya untuk dapat bertahan dalam persaingan, perusahaan membutuhkan filosofi baru. Perusahaan yang berfilosofi dan berwawasan pelangganlah yang akan unggul dalam persaingan, karena mereka bisa memberikan nilai yang lebih baik kepada pelanggan dibanding pesaingnya. Mereka juga akan lebih mudah mendapatkan pelanggan, bukan hanya mahir membuat produk, merekayasa produk dan merekayasa pasar.

"Kepuasan adalah tingkat perasaan seseorang setelah membandingkan kinerja (atau hasil) yang dia rasakan dibandingkan dengan harapannya." (Kotler P. dan Susanto A. B.,1999).

Jadi, tingkat kepuasan adalah fungsi dari perbedaan antara kinerja vang dirasakan dengan harapaii. Pelanggan dapat mengalami salah satu dari tiga tingkat kepuasan yang umum. Kalau kinerja di bawah harapan, pelanggan kecewa. Kalau kinerja sesuai harapan, pelanggan puas. Kalau kinerja melebihi harapan, pelanggan sangat puas, senang, atau gembira.

\section{Hubungan Kualitas Jasa dengan Kepuasan Pelanggan.}

Mutu dan pelayanan adalah sarana untuk mencapai kepuasan pelanggan. Tujuan keseluruhan perusahaan bukanlah untuk menghasilkan produk atau jasa yang bermutu, atau memberikan pelayanan yang prima. Tujuan utama perusahaan adalah menghasilkan pelanggan yang puas dan setia yang akan terus menjalin bisnis dengan perusahaan. Oleh karena itu, memberikan mutu yang tinggi dan pelayanan yang prima adalah suatu keharusan apabila perusahaan ingin mencapai tujuan utama yaitu pelanggan yang puas dan setia.

Untuk mewujudkan dan mempertahankan kepuasan pelanggan, perusahaan jasa harus melakukan empat hal, yaitu:

1. Mengidentifikasi siapa pelanggannya.

2. Memahami tingkat harapan pelanggan atas kualitas 
3. Memahami strategi kualitas layanan pelanggan.

4. Memahami siklus pengukuran dan umpan balik dari kepuasan pelanggan.

\section{MIPOTESA}

Kepuasan pelanggan adalah persepsi pelanggan bahwa harapannya telah terpenuhi atau terlampaui. Kepuasan pelanggan dapat dicapai dengan pemenuhan mutu/kualitas dan layanan yang sesuai dengan persepsi pelanggan. Mutu pelayanan yang baik akan memberikan kepuasan konsumen yang pada akhirnya berdampak pada penggunaan jasa layanan travel secara berkesinambungan. Hubungan antara kualitas pelayanan dan kepuasan pelanggan bersifat positif, yaitu apabila kualitas pelayanan semakin baik maka kepuasan pelanggan akan semakin meningkat.

Berdasar pada tinjauan literatur maka usulan penelitian ini akan menilai kualitas dimensi mutu TSQM dengan mengacu pada lima dimensi mutu TSQM yaitu: mutu fisik, pendukung mutu fisik, mutu perusahaan/lembaga, mutu teknikal, dan mutu interaktif. Maka, sebagai pedoman arah penelitian mak histesisnya adalah:

H1: Ada pengarun mmens: mutu fisik lerhadap kepuasan pelanggan.

H2: Ada pengaruh dimensi pendukung mutu fisik terhadap kepuasan pelanggan.

H3: Ada pengaruh dimensi mutu perusahaan/lembaga terhadap kepuasan pelanggan.

H4: Ada pengaruh dimensi mutu teknikal terhadap kepuasan pelanggan.

H5: Ada pengaruh ciirrensi mutu interaktif terhadap kepuasan pelanggan.

H6: Ada pengaruh dimensi mutu yang terdiri dari dimensi mutu fisik, pendukung mutu fisik, mutu perusahaan/lembaga, mutu teknikal, dan mutu interaktif terhadap kepuasan pelanggan.

Gambar 2

Model Penelitian

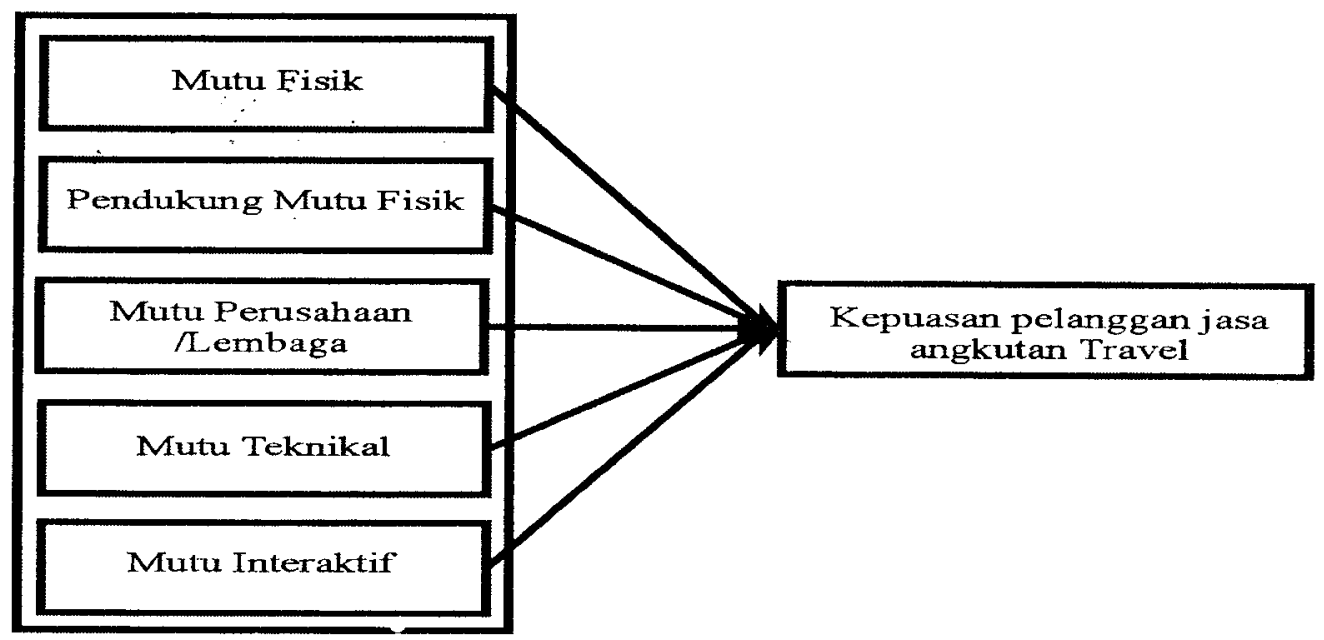

\section{Model Penelitian}

Berdasarkan hipotesis di atas, maka dapat digambarkan model penelitian pada Gambar 2. Pensliti meneliti pengaruh dimensi mutu TSQM dimana variabel mutu fisik, pendukung mutu fisik, mutu perusahaan/lembaga, mutu teknikal, mutu interaktif mempengaruhi kepuasan pelanggan jasa Persada Tour \& Travel.

\section{METODOLOGI}

Subyek penelitian ini adalah pelanggan atau pengguna jasa layanan transportasi Persada Tour \& Travel di Yogyakarta. Jenis Data yang digunakan dalam penelitian ini adalah data primer, Teknik pengambilan data menggunakan metode survei dengan menggunakan kuesioner.

Teknik pengambilan sampel yang digunakan yaitu, purposive sampling, dengan kriteria pelanggan jasa angkutan Persada Tour \& Travel yang berada di agen Persada Tour \& Travel Yogyakarta dan atau pelanggan yang menggunakan jasa transportasi Persada Tour \& Travel minimal satu kali, karena pelanggan jasa yang berada di agen Persada Tour \& Travel Yogyakarta dan pernah menggunakan jasa transportasinya dinilai lebih menggunakan fasilitas dan layanan jasa dari pihak perusahaan.

\section{Definisi Operasional Variabel Penelitian}

Pada penelitian ini kepuasan pelanggan jasa angkutan Persada Tour \& Travel sebagai variabel dependen. Kepuasan dalam hal ini diartikan sebagai tingkat perasaan seseorang seteiah membandingkan kinerja (atau hasil) yang dia rasakan dibandingkan dengan harapannya (Kotler P. \& Susanto A.B.,1999). Pada penelitian ini, kepuasan dari pelanggan jasa Persada Tour \& 
Travel diukur dari seberapa besar tingkat kualitas pelayanan yada Persada Tour \& Travel Yogyakarta Yang diterima dan dirasakan oleh pelanggan jasa tersebut.

Variabel Independen dalam penelitian ini terdiri dari lima dimensi mutu TSQM yang dikemukakan oleh Said Dj., (2004) dengan penyesuaian pada obyek penelitian, yaitu :

(1) Mutu fisik $\left(X_{1}\right)$, adalah mutu/kualitas dari segi fisik (bangunan) yang mampu mempengaruhi kepuasan pelanggan. Mutu fisik dari obyek penelitian ini yaitu; kondisi fisik ruang tunggu, kondisi fisik mobil, tata ruang tunggu, kenyamanan dan kebersihan di dalam mobil, kenyamanan dan kebersihan di ruang tunggu, serta ukuran dan mutu tempat duduk penumpang di dalam mobil.

(2) Mutu pendukung fisik $\left(\mathrm{X}_{2}\right)$, adalah mutu/kualitas yang mendukung kinerja/manfaat dari fasilitas fisik yang dapat mempengaruhi kepuasan pelanggan. Mutu pendukung fisik dari obyek penelitian ini yaitu; alat perlengkapan keselamatan, transport lanjutan, ruang parkir kendaraan, ruang tunggu, fasilitas didalam ruang tunggu, dan fasilitas didalam mobil.

(3) Mutu perusahaan/lembaga $\left(\mathrm{X}_{3}\right)$, adalah mutu/kualitas dari perusahaan/lembaga penyedia layanan, yang dapat mempengaruhi kepuasan pelanggan dan biasanya didasarkan pada kinerja operasional perusahaan. Mutu perusahaan/lembaga pada obyek penelitian ini yaitu; tepat waktu keberangkatan dari cutlet ketempat tujuan, tepat waktu kedatangan mobil di outlet, kemudahan mendapatkan tiket, dedikasi pegawai, kenyamanan, dan tanggung jawab/jaminan keselamatan dari perusahaan.

(4) Mutu teknikal $\left(\mathrm{X}_{4}\right)$, adalah mutu/kualitas dari segi teknis dalam hal pelayanan yang dapat mempengaruhi kepuasan pelanggan. Mutu teknikal dari obyek penelitian ini yaitu; pengetahuan pegawai dalam bidang pelayanan, pengetahuan pegawai dalam bidang pelanggan, pengetahuan pegawai dalam bidang kerjanya, kecepatan dan ketelitian pegawai dalam bekerja.

(5) Mutu interaktif $\left(X_{5}\right)$ adalah mutu/kualitas yang dinilai dengan performa dan kualitas interaktif atau kemampuan berkomunikasi pihak perusahaan dengan pelanggan, dan hal itu dapat mempengaruhi kepuasan pelanggan tersebut. Mutu interaktif dalam obyek penelitiar ini yaitu; memberikan informasi pada pelanggan, penanganan keluhan pelanggan, penanganan dalam kecelakaan, kejujuran pegawai dalam bekerja, keramahan pegawai dalam bekerja, mental pegawai dalam pelayanan, memecahkan masalah dengan cepat, koordinasi kerja pegawai dalam menangani masalah, memberikan enpati pada pelanggan, dan saling pengertian/toleransi.

Pada penelitian ini, kepuasan dari pelanggan diukur dari seberapa besar tingkat kualitas pelayanan yang diterima dan dirasakan oleh pelanggan jasa tersebut. Masing-masing data survei tersebut akan diukur dengan item pertanyaan dengan menggunakan skala Likert. Skala Likert merupakan metode yang mengukur sikap dengan peryataaan setuju atau tidak setuju terhadap pertanyaan yang diajukan dalam kuesioner. Peneliti memberikan kuesioner yang disusun dalam bentuk pertanyaan dan disediakan kolom jawaban yang menyatakan (1) sangat tidak setuju, (2) tidak setuju, (3) netral, (4) setuju, (5) sangat setuju.

\section{HASIL PENELITIAN DAN PEMBAHASAN}

Persada Tour \& Travel merupakan salah satu perusahaan otobus penyedia jasa layanan transportasi yang berkantor pusat di Jl. Raya Depan Pasar Limpung, Batang, Jawa Tengah. PO Persada Transport merupakan perusahaan otobus yang melayani trayek Pekaiongan-Sukorejo. Perusahaan yang berdiri sejak tahun 1991 ini berhasil mengembangkan bisnisnya dengan menambah armada bus yang pada awalnya hanya memiliki 4 buah armada bus saat ini menjadi 20 armada bus.

Pada awal tahun 2005. Persada Transport melakukan manuver bisnis dengai memperkenalkan inovasi bisnis terbarunya dengan promosi inovativ. Persada Tour \& Travel merupakan jasa layanan transportasi yang menggunakan mobil pribadi atau lebih dikenal dengan sebutan travel. Trayek pertama yang dilayani oleh Persada Tour \& Travel adalah Pekalongan-Yogyakarta. Manajemen mempunyai alasan mengapa trayek Pekalongan-Yogyakarta yang dipilih, menurut mereka banyak masyarakat Yogyakarta yang pindah ke Pekalongan dan sekitarnya karena tuntutan pekerjaan. Begitu pula dengan mahasiswa yang mengenyam pendidikan di Yogyakarta berasal dari daerah Pekalongan dan sekitarnya.

Kesuksesan yang dicapai Persada Transport membutuhkan konsentrasi ekstra bagi manajemen untuk dapat bertahan dan lebih mengembangkan lagi bisnisnya. Fokus pada pelanggan merupakan hal yang sangat diperhatikan oleh manajemen Persada karena menurut manajemen Persada, kepuasaan pelangganlah yang menjadi faktor utama dalam mempertimbangkan penggunaan kembali.

Fokus pada pelanggan berarti memberikan pelayanan yang sesuai dengan harapan pelanggan. Kepuasan pelanggan dapat 
dicapai apabila manajemen dapat memenuhi 5 dimensi Total Service Quality Management (TSQM) yaitu mutu fisik, pendukung mutu fisik, mutu perusahaan/lembaga, mutu tekniks! dan mutu interaktif. Sebagai perusahaas yang telah lama berkecimpung dibidang transportasi Persada sangat memahami pentingnya kualitas/mutu bagi pelanggan.

Aspek pertama yang dapat dilihat secara langsung oleh calon pelanggan adalah mutu fisik. Kondisi fisik ruang tunggu, kondisi fîsik movil tatá ruang tunggu dan kenyamanan di dalam ruang tunggu dan maupun di dalam mobil menjadi perhatian manajemen. Manajemen menyediakan ruang tunggu seluas $5 \times 6 \mathrm{~m}$ yang diatur sedemikian rupa bertujuan untuk memberikan kenyamanan pada saat pelanggan menunggu kedatangan/keberangkatan mobil. Persada Tour \& Travel menggunakan 2 jenis mobil yang bertenaga besar dan dirasa mampu untuk memberikan kenyamanan karena tempat duduknya lebih besar dibanding mobil jenis lain, yaitu Mitsubishi L300 tahun 2008 dan ELF tahun 2007.

Pendukung mutu fisik yang diberikan Persada Tour \& Travel dengan menyediakan Pertolongan Pertama Pada Kecelakaan (P3K) disetiap mobil sehingga dapat melakukan tindakan penyelamatan pertama jika terjadi kecelakaan. Letak strategis agen Persada tour \& Travel yang, berada di tepi Jl. Diponegoro membuat jara pelanggan lebih mudah mendapatkan transpiortasi lanjutan dan tempat parkir yang mencukupi. Penyediaan ruang tunggu yang bersih dan memiliki fasilitas berupa Air Conditioner (AC). televisi dan kamar mandi bertujuan untuk memberikan kenyamanan bagi pelanggan. Persada Tour \& Travel tidak hanya menyediakan fasilitas di ruang tunggu saja, akan tetapi juga menyediakan fasilitas didalam mobil, seperti bantal dan selimut.

Mutu perusahaan/lembaga Persada Tour $\&$ Travel sudah sangat teruji, hal ini dapat dilihat dari ketepatan kedatangan dan keberangkatan mobil serta kemudahan pelanggan dalam mendapatkan tiket. Persada Tour \& Travel mempekerjakan karyawan yang berdedikasi agar dapat melayani pelanggan dengan baik. Sebagai perusahaan yang telah lama berkecimpung pada bidang tranşportasi Persada Tour \& Travel memberikan asuransi bagi setiap pelanggan yang menggunakan jasa layanan transportasinya guna meminimalisir rasa khawatir pelanggan.

Tabel 1.

Gambaran Hasil Jawaban Responden

\begin{tabular}{|c|l|c|c|}
\hline No & \multicolumn{1}{|c|}{ Pertanyaan } & Skor Total & Rata-rata \\
\hline & \multicolumn{1}{|c|}{ Mutu Fisik } & & \\
\hline 1 & Kondisi fisik ruang tunggu baik & 133 & 3.4 \\
\hline 2 & Kondisi fisik mobil layak & 150 & 3.8 \\
\hline 3 & Tata ruang tunggu baik & 127 & 3.5 \\
\hline 4 & Kenyamanan \& kebersihan di ruang tunggu terjaga & 142 & 3.6 \\
\hline 5 & Kenyamanan dan kebersihan di mobil terjaga & 132 & 3.4 \\
\hline 6 & Ukuran \& mutu tempat duduk di mobil sudah baik & 138 & 3.5 \\
\hline
\end{tabular}

\begin{tabular}{|c|l|c|c|}
\hline & \multicolumn{1}{|c|}{ Pendukung Mutu Fisik } & & \\
\hline 7 & Alat perlengkapan keselamatan tersedia & 122 & 3.1 \\
\hline 8 & Transport lanjutan setelah naik travel mudah & 131 & 3.3 \\
\hline 9 & Ruang parkir kendaraan kuas dan aman & 127 & 3.6 \\
\hline 10 & Fasilitas ruang tunggu tersedia & 132 & 3.4 \\
\hline 11 & Fasilitas diruang tunggu bersih, lengkap \& nyaman & 129 & 3.3 \\
\hline 12 & Fasilitas didalam mobil bersih, lengkap dan nyaman & 137 & 3.5 \\
\hline
\end{tabular}

\begin{tabular}{|c|l|c|c|}
\hline & \multicolumn{1}{|c|}{ Mutu Perusahaan/Lembaga } & & \\
\hline 13 & Keberangakatan mobil tepat waktu & 124 & 3.2 \\
\hline 14 & Kedatangan mobil tepat waktu & 125 & 3.2 \\
\hline 15 & Mudah dalam mendapatkan tiket & 142 & 3.6 \\
\hline 16 & Dedikasi para pegawai baik & 135 & 3.5 \\
\hline 17 & Travel lebih nyaman dibanding transportasi lainya & 141 & 3.6 \\
\hline 18 & Perusahaan memberi asuransi keselamatan & 133 & 3.4 \\
\hline
\end{tabular}

\begin{tabular}{|l|l|c|c|}
\hline & \multicolumn{1}{|c|}{ Mutu teknikal } & & \\
\hline 19 & Pegawai paham dalam bidang pelayanan & 136 & 3.5 \\
\hline 20 & Pegawai paham akan keinginan pelanggan & 134 & 3.4 \\
\hline 21 & Pegawai mempunyai kemampuan kerja yang baik & 139 & 3.6 \\
\hline
\end{tabular}




\begin{tabular}{|l|l|l|l|}
\hline 22 & Pegawai cekatan dan teliti dalam bekerja & 134 & 3.3 \\
\hline
\end{tabular}

\begin{tabular}{|c|l|c|c|}
\hline \multicolumn{1}{|c|}{ Mutu Intral } & Skor total & Rata-rata \\
\hline 23 & Perusahaan memberikan informais pada pelanggan & 133 & 3.4 \\
\hline 24 & $\begin{array}{l}\text { Perusahaan memberikan penanganan keiuhan } \\
\text { dengan baik }\end{array}$ & 1.3 & 3.4 \\
\hline 25 & $\begin{array}{l}\text { Perusahaan melakukan peranganan dengan baik } \\
\text { jika terjadi kecelakaan. }\end{array}$ & 131 & 3.4 \\
\hline 26 & Pegawai selalu jujur dalam bekerja & 128 & 3.3 \\
\hline 27 & Pegawai ramah dalam bekerja & 135 & 3.5 \\
\hline 28 & Pagawai memiliki mental yang baik dalam bekerja & 134 & 3.4 \\
\hline 29 & Pegawai melakukan koordinasi kerja dengan baik & 134 & 3.4 \\
\hline 30 & Pegawai cepat dalam menangani masalah & 131 & 3.4 \\
\hline 31 & Pegawai empati pada pelanggan & 130 & 3.3 \\
\hline 32 & Pegawai sangat toleransi dengan pelanggan. & 134 & 3.4 \\
\hline
\end{tabular}

Perekrutan pegawai yang berkualitas oleh manajemen diharapkan mampu memberikan kualitas pelayanan yang baik bagi para pelanggan. Pegawai selalu dituntut untuk dapat memahami bidang pelayanan, memăhami keinginan konsumen, mempunyai kemampuan dalam pelayanan serta cekatan dan teliti dalam pekerjaanya. Semua faktor-faktor tersebut diharapkan dapat meningkatkari mutu teknikal di mata pelanggan.

Dalam hal mutu interaktif perusahaan dengan pelanggannya, Persada Tour \& Travel selalu memberikan informasi melalui telepon apabila terjadi penundaan keberangkatan atau kedatangan mobil. Persada Tour \& Travel memberikan penanganan keluhan dan penanganan bila terjadi kecelakaan.

Pada Tabel 1 dapat dilihat bahwa pada dimensi mutu fisik, kondisi fisik mobil menjadi faktor yang mampu memberikan tingkat kepuasan tertinggi di mata pelanggan dengan nilai rata-rata sebesar 3,8. Pada dimensi pendukung mutu fisik ruang parkir kendaraan yang luas dan baik menjadi pendukung mutu fisik terbaik dengan nilai rata-rata 3,6. Pada dimensi mutu perusahaan/lembaga kemudahan mendapatkan tiket dan perasaan kenyamanan pelanggan menggunakan travel dibanding transportasi lainya menjadi faktor terbaik pada mutu perusahaan/ lembaga dengan nilai 3,6. Pada mutu teknikal kemampuan yang baik dari pegawai dalam bidang kerjanya memiliki nilai tertinggi dengan nilai rata-rata 3,6. Pada mutu interaktif keramahan pegawai menjadi faktor terbaik bagi pelanggan dengan nilai rata-rata 3.5 .

\section{Analisis Regresi Linier Berganda.}

Analisis dimaksudkan untuk mengetahui pengaruh dari variabel TSQM yang terdiri mutu fisik, pendukung mutu fisik, mutu perusahaan, mutu teknikal, dan mutu interaktif terhadap kepuasan pelanggan. Hasil perhitungan analisis regresi dapat dilihat pada Tabel 2.

a. Koefisien variabel mutu fisik (Xl) sebesar 0.166 artinya (X1) mempunyai arah hubungan yang positif terhadap (Y). Peningkatan mutu fisik di agen Yogyakarta akan meningkatkan kepuasan pelanggan, sebaliknya penurunan mutu fisik akan menurunkan kepuasan pelanggan.

b. Koefisien variabel pendukung mutu fisik (X2) sebesar 0.229 artinya (X2) mempunyai arah hubungan yang positif terhadap (Y). Peningkatan pendukung mutu fisik di agen Yogyakarta akan meningkatkan kepuasan pelanggan, sebaliknya penurunan pendukung mutu fisik akan menurunkan kepuasan pelanggan.

Tabel 2

Hasil Analisis Regresi dan Uji t

\begin{tabular}{|c|c|c|c|c|c|}
\hline & \multicolumn{2}{|c|}{ Unstandardized Coefficient } & $\begin{array}{c}\text { Standardized } \\
\text { Coefficients }\end{array}$ & & Sig. \\
\hline Model & B & Std. Error & Beta & $t$ & .603 \\
\hline (Constant) & .129 & .246 & & .525 & .047 \\
\hline $\mathrm{X} 1$ & .138 & .067 & .166 & 2.062 & .026 \\
\hline $\mathrm{X} 2$ & .177 & .076 & .229 & 2.332 & .019 \\
\hline $\mathrm{X} 3$ & .255 & .104 & .249 & 2.459 & .036 \\
\hline $\mathrm{X} 4$ & .204 & .093 & .237 & 2.185 & .035 \\
\hline
\end{tabular}

c. Koefisien variabel mutu perusahaan/lembaga (X3) sebesar 0.249 artinya (X3) mempunyai arah hubungan yang positif terhadap (Y)
Peningkatan mutu perusahaan/lembaga di agen Yogyakarta akan meningkatkan kepuasan pelanggan, sebaliknya penurunan 
mutu perusahaan/lembaga di Persada Tour \& Travel Yogyakarta akan menurunkan kepuasan pelanggan.

¿. Koefisien variabel mutu teknikal (X4) sebesar 0.237 artinya (X4) mempunyai arah hubungan yang positif terhadap (Y). Peningkatan mutu teknikal di agen Yogyakarta akan meningkatkan kepuasan pelanggan, sebaliknya penurunan mutu teknikal di agen Persada Tour \& Travel Yogyakarta akan menurunkan kepuasan pelanggan.

c. Koefisien variabel mutu interaktif (X5) sebesar 0.234 artinya (X5) mempunyai arah hubungan yang positif terhadap (Y). Peningkatan mutu interaktif di agen Yogyakarta akan meningkatkan kepuasan pelanggan, sebaliknya penurunan mutu interaktif di agen Persada Tour \& Travel Yogyakarta akan menurunkan kepuasan pelanggan.

t. Nilai koefisien variabel mutu perusahaan/lembaga (X3) sebesar 0.249 lebih besar daripada nilai koefisien variabel mutu fisik (X1), pendukung mutu fisik (X2), mutu teknikal (X4), dan variabel mutu interaktif (X5). Hal ini menunjukkan bahwa variabel mutu perusahaan/lembaga (X3) merupakan variabel yang paling berpengaruh terhadap kepuasan pelanggan.

\section{Analisis Uji t}

Pengujian secara parsial (t-test) dilakukan untuk melihat signifikansi dari pengaruh variabel bebas (mutu fisik, pendukung mutu fisik, mutu perusahaan/lembaga, mutu teknikal dan mutu interaktif) secara individual terhadap variabel terikat (kepuasan pelanggan). Hasil uji $\mathbf{t}$ disajikan pada Tabel 2

Berdasarkan hasil uji t pada penelitian ini diperoleh hasil sebagai berikut:

Pengujian H1, yaitu; "Ada pengaruh dimensi mutu fisik terhadap kepuasan pelanggan". Diketahui nilai signifikansi variabel mutu fisik (X1) sebesar 0.047 dimana nilai tersebut lebih kecil dari taraf signifikansi yang digunakan yaitu 0.05 . Hasil tersebut menunjukkan bahwa variabel mutu fisik (X1) berpengaruh signifikan terhadap kepuasan pelanggan (Y), yang berarti menunjukkan bahwa Hl diterima.

Penguian H2, yaitu: "Ada pengaruh dimensi perdikung mutu fisik terhadap kepuasan monggan". Diketakui nilai signifikansi variabel pendukung mutu fisik (X2) sebesar 0.026 dimana nilai tersebut lebin kecil dari taraf signifikansi sang diginakan yaitu 0.05 . Hasi] tersebut menunjukkan bahwa variabel Pendukung mutu fisik (X2) berpengaruh signifikan terhadap kepuasan pelanggan (Y), yang berarti menunjukkan bahwa $\mathrm{H} 2$ diterima.

Pengujian H3, yaitu; "Ada pengaruh dimensi mutu perusahaan/lembaga terhadap kepuasan pelanggan". Diketahui nilai signifikansi variabel mutu perusahaan/lembaga (X3) sebesar 0.019 dimana nilai tersebut lebih kecil dari taraf signifikansi yang digunakan yaitu 0.05. Hasil tersebut menurijukkan bahwa variabel mutu perusahaan/lembaga (X3) berpengaruh signifikan terhadap kepuasan pelanggan ( $Y$ ), yang berarti menunjukkan bahwa H3 diterima. Pengujian H4, yaitu; "Ada pengaruh dimensi mutu teknikal terhadap kepuasan pelanggan". Diketahui nilai signifikansi variabel mutu teknikal (X4) sebesar 0.036 dimana nilai tersebut lebih kecil dari taraf signifikansi yang digunakan yaitu 0.05 . Hasil tersebut menunjukkan bahwa variabel mutu teknikal (X4) berpengaruh signifikan terhadap kepuasan pelanggan (Y), yang berarti menunjukkan bahwa $\mathrm{H} 4$ diterima.

Pengujian H5, yaitu; "Ada pengaruh dimensi mutu interaktif terhadap kepuasan pelanggan". Diketahui nilai signifikansi variabel mutu interaktif $(\mathrm{X} 4)$ sebesar 0.035 dimana nilai tersebut lebih kecil dari taraf signifikansi yang digunakan yaitu 0.05. Hasil tersebut menunjukkan bahwa variabel mutu interaktif (X5) berpengaruh signifikan terhadap kepuasan pelanggan $\left(Y^{\prime}\right)$, yang berarti menunjukkan bahwa $\mathrm{H} 5$ diterima.

\section{Analisis Uji F}

Pengujian secara simultan ( $F$ test) dilakukan untuk melihat signifikansi dari pengaruh variabel bebas (mutu fisik, peildukung mutu fisik, mutu perusahaan/lembaga, mutu teknikal dan mutu interaktif) secara serentak/bersama-sama terhadap variabel terikat (kepuasan pelanggan). Hasil uji $\mathrm{F}$ dapat dilihat pada Tabel 3 di bawah ini.

Tabel 3.

Hasil Uji F

\begin{tabular}{|l|r|r|r|r|r|}
\hline \multicolumn{1}{|c|}{ Model } & Sum of Squares & df & Mean Square & F & Sig \\
\hline Regession & 10.410 & 5 & 2.082 & 43.671 & \\
\hline Residual & 1.573 & 33 & .048 & & \\
\hline Total & 11.984 & 38 & & & \\
\hline
\end{tabular}

Uji $F$ bertujuan untuk menguji $\mathrm{H} 6$ penelitian ini yaitu; "Ada pengaruh dimensi mutu yang terdiri dari dimensi mutu fisik, pendukung mutu fisik, mutu perusahaan/lembaga, mutu teknikal, dan mutu interaktif terhadap kepuasan pelanggan". Berdasarkan hasil uji $\mathrm{F}$ diperoleh nilai 
signifikansi $F$ test sebesar $0.000<0.05$ yang berarti signifikan, dan dapat disimpulkan secara serempak atau bersama-sama variabel mutu fisik, pendukung mutu fisik, mutu perusahaan/lembaga, mutu teknikal, dan mutu interaktif yang merupakan dimensi mutu dari Total Service Quality Management berpengaruh signifikan terhadap kepuasan pelanggan, yang berarti menunjukkan $\mathrm{H6}$ diterima.

\section{Analisis Koefisien Determinasi}

Analisis ini dilakukan menggunakan analisis koefisien determinasi Adjusted $R$ Square dari persamaan regresi berganda dan uji $F$ sebagai uji signifikunsinya. Hasil analisis koefisien determinas 4 ther $R$ Sorre dapat dilihat pada Tabel 4, yang diketanui uahwa hasil pengujian koefisien determinasi diperoleh nilai Adjusted $R$ Square sebesar 0.849. Nilai Adjusted $R$ Square tersebut menunjukkan bahwa $84.9 \%$ variasi dari kepuasan pelanggan Persada Tour \& Travel di agen Yogyakarta mampu dijelaskan oleh variasi variabel mutu fisik, pendikung mutu fisik, mutu perusahaan/lembaga, mutu teknikal dan mutu interaktif.

Tabel 4

Hasil Analisis Koefisien Determinasi

\begin{tabular}{|c|r|r|r|r|}
\hline Model & R & R Square & $\begin{array}{c}\text { Adjusted R } \\
\text { Square }\end{array}$ & $\begin{array}{c}\text { Std. Error of the } \\
\text { Estimate }\end{array}$ \\
\hline $\mathrm{l}$ & .932 & .869 & .849 & .21835 \\
\hline
\end{tabular}

\section{Pembahasan}

Berdasarkan hasil Uji t diketahui bahwa variabel mutu fisik berpengaruh signifikan terhadap kepuasan pelanggan dengan nilai signifikasi 0.047 atau lebih kecil dari 0.05 , yang berarti semakin baik/tinggi mutu fisik dari Persada Tour \& Travel Yogyakarta maka pelanggan semakin puas. Kualitas pelayanan pada dimensi mutu fisik menunjukkan bahwa kondisi fisik (bangunan) ruang tunggu, kondisi mobil tata ruang tunggu, kenyamanan dan kebersihan di dalam mobil, kenyamanan dan kebersihan di ruang tunggu, serta ukuran dan mutu tempat duduk penumpang dalam mobil yang baik dapat meningkatkan kepuasan pelanggan.

Variabel pendukung mutu fisik berpengaruh signifikan terhadap kepuasan pelanggan dengan nilai signifikasi 0.026 atau lebih kecil dari 0.05 , yang berarti semakin baik/tinggi pendukung mutu fisik, maka pelanggan semakin puas. Kualitas pelayanan pada dimensi pendukung mutu fisik menunjukkan bahwa alat perlengkapan keselamatan, transport lanjutan, ruang parkir, fasilitas dalam ruang tunggu, fasilitas di dalam ruang tunggu, serta fasilitas didalam mobil yang baik dan memadai dapat meningkatkan kepuasan dan loyalitas bagi pelanggan.

Variabel mutu perusahaan/lembaga berpengaruh signifikan terhadap kepuasan pelanggan dengan nilai signifikasi 0.19 atau lebih kecil dari 0.05 , yang berarti semakin baik/tinggi mutu perusahaan lembaga pada agen Persada Tour \& Travel Yogyakarta, maka pelanggan semakin puas. Kualitas pelayanan pada dimensi mutu perusahaan/lembaga menunjukkan bahwa ketepatan waktu keberangkatan mobil, ketepatan waktu kedatangan mobil, kemudahan mendapatkan tiket, dedikasi pegawai, kenyamanan jasa transportasi travel, dan jaminan keselamatan (asuransi) yang diberikan dengan baik dapat meningkatkan kepuasan dan loyalitas bagi pelanggan.

Variabel mutu teknikal berpengaruh signifikan terhadap kepuasan pelanggan dengan nilai signifikasi 0.036 atau lebih kecil dari 0.05 , yang berarti semakin baik/tinggi mutu teknikal pada Persada Tour \& Travel Yogyakarta, maka pelanggan semakin puas. Kualitas pelayanan di agen Persada Tour \& Travel Yogyakarta pada dimensi mutu tenikal menunjukkan bahwa pengetahuan/tingkat kepahaman pegawai dalam bidang pelayanan, pengetahuan/tingkat pemahaman akan keinginan pelanggan, kemampuan pegawai dalam bidang kerjanya, serta kecekatan pegawai dalam bekerja dapat meningkatkan kepuasan bagi pelanggan.

Variabel mutu interaktif berpengaruh signifikan terhadap kepuasan pelanggan dengan nilai signifikasi sebesar 0.035 atau lebih keci dari 0.05 , yang berarti semakin baik/tinggi mutu interaktif yang diberikan staf/pegawai di agen Yogyakarta, maka pelanggan semakin puas. Kualitas pelayanan di agen Yogyakarta pada dimensi mutu interaktif menunjukkan bahwa informasi bagi pelanggan, penanganan keluhan pelanggan, penanganan bila terjadi kecelakaan, kejujuran para pegawai, keramahan para pegawai, mental fara pegawai, koordinasi kerja para pegawai, kecepatan pegawai dalam menangani masalah, empati pegawai pada pelanggan, serta tingkat pengertian/toleransi pegawai yang diberikan dengan baik dapat meningkatkan kepuasan dan loyaiitas bagi pelanggan.

Berdasarkan hasil uji $\mathrm{F}$ dapat diketahui bahwa dari lima variabel mutu, semuanya memiliki pengaruh terhadap kepuasan pelanggan dengan nilai signifikasi 0.000 atau lebih kecil dari 0.05 , hal ini menunjukkan bahwa Total Service 
Quality Management yang diwujudkan dalam 5 dimensi mutu yaitu; mutu fisik, pendukung mutu fisik, mutu perusahaan/lembaga, mutu teknikal, dan mut atartir mempengaruhi kepuasan pelangan.

Hasil penelitian ini sesuai dengan hipoteris yang diajukan, yaitu ada pengaruh dimensi mutu yang terdiri dari dimensi mutu fisik, pendukung mutu fisik, mutu perusahaan/lembaga, mutu teknikal, dan mutu interaktif terhadap kepuasan pelaiiggan, baik secara parsial ataupun secara simultan.

Berdasarkan hasil penelitian, dimensi mutu perusahaan/lembaga merupakan dimensi yang paling berpengaruh terhadap kepuasan pelanggan dengan nilai signifikasi 0.019 atau lebih kecil dari dimensi mutu fisik $(0.047)$, pendukung mutu fisik (0.026), mutu teknikal (0.036) dan mutu interaktif (0.035). Hal tersebut karena mutu perusahaan /lembaga merupakan hal yang paling utama yang inendasari kepuasan pelanggan, adapun hal tersebut terdiri dari ketepatan keberangkatan mobil, ketepatan kedatangan mobil, kemudahan dalam mendapatkan tiket, dedikasi para pegawai yang baik, kenyamanan yang didapatkan pelanggan saat menggunakan travel dan pemberian asuransi bagi pelanggan.

Implikasi hasil penelitian ini sangat bermanfaat bagi manajemen perusahaan travel khususnya di agen Yogyakarta sebagai bahan pertimbangan dalam usaha meningkatkan dan memperbaiki kualitas pelayanan. $\mathrm{Hal}$ ini disebabkan pentingnya kualitas layanan bagi sebuah perusahaan jasa termasuk bidang transportasi, karena perusahaan jasa transportasi merupakan suatu perusahaan jasa yang banyak digunakan masyarakat. Perusahaan jasa transportasi bahkan menjadi tumpuan mobilitas bagi banyak pelanggan jasanya di setiap saat.

Sejak awal didirikan, perusahaan telah berusaha meningkatkan kualitas layanan secara terus menerus, dengan berusaha lebih meningkatkan kualitas kerja pegawai, kualitas mobil yang digunakan, bangunan agen, teknologi yang digunakan, seria kualitas berbagai bidang yang menunjang kelancaran dan keberhasilan kegiatan operasional perusahaan. Berkaitan dengan itu maka dimensi konsumen, sangat menentukan perbaikan di bidang kualitas pelayanan, karena pada dasarnya untuk mengetahui tingkat kualitas layanan adalah berorientasi pada konsumen.

Usaha perbaikan kualitas layanan tersebut akan lebih baik bila dilakukan secara menyeluruh pada masing-masing bagian di perusahaaan dengan mengacu pada 5 dimensi yang terdiri dari mutu fisik, pendukung mutu fisik, mutu perusahaan/lembaga, mutu teknikal, dan mutu interaktif.

\section{SIMPULAN, SARAN DAN KETERBATASAN PENELITIAN \\ Simpulan}

Pada penelitian in peneity moraji pengaruh Total Serves Quality Marrgenent terhadap kepuasan Pelanggan yang menggunakan 5 dimensi mutu yang dikemukakan olehr Said Dj. (2004) yaitu dimensi mutu fisik, dimensi pendukung mutu fisik, dimensi mutu perusahaan /lembaga, dimensi mutu teknikal dan dimensi mutu interaktif. Berdasarkan hasil penelitian dan anaîsis data yang telah diuraikan dalam bab sebelumnya, maka diperoleh kesimpulan bahwa:

1. Mutu fisik berpengaruh signifikan terhadap kepuasan pelanggan

2. Pendukung mutu fisik berpengaruh signifikan terhadap kepuasan pelanggan

3. Mutu Perusahaan/lembaga berpengaruh signifikan terhadap kepuasan pelainggan

4. Mutu Teknikal berpengaruh signifikan terhadap kepuasan pelanggan

5. Mutu interaktif berpengaruh signifikan terhadap kepuasan pelanggan

6. Berdasarkan pada $F$ test menunjukkan secara serempak atau bersama-sama variabel Mutu Fisik, Pendukung Mutu Fisik, Mutu Perusahaan/Lembaga, Mutu Teknikal, dan Mutu Interaktif yang merupakan dimensi mutu dari Total Service Quality Management (Said Dj., 2004) berpengaruh signifikan terhadap kepuasan pelanggan jasa Persada Tour \& Travel di agen Yogyakarta.

\section{Saran}

1. Pihak perusahaan, khususnya di agen Yogyakarta hendaknya lebih memperhatikan dan meningkatkan kualitas layanannya pada kelima dimensi kualitas layanan yang selama ini sudah dilakukan. Hal tersebut dikarenakan pada penelitian ini terbukti bahwa 5 dimensi TSQM yang terdiri dari dimensi Mutu Fisik, Pendukung Mutu Fisik, Mutu Perusahaan/Lembaga, Mutu Teknikal, dan Mutu Interaktif memiliki pengaruh yang signifikan terhadap kepuasan pelanggan. Berkaitan dengan hal tersebut maka dimensi konsumen, sangat menentukan perbaikan bagi manajemen di bidang kualitas pelay'anan bagi pihak perusahaan, karena pada dasarnya untuk mengetahui tingkat kualitas layanan adalah berorientasi pada pelanggan.

2. Berdasarkan hasil penelitian, dimensi mutu perusahaan/lembaga merupakan dimensi yang memiliki pengaruh paling signifikan. Perusahaan hendaknya memprioritaskan kualitas layanan pada dimensi mutu perusahaan/lembaga, yaitu dengan memperbaiki kualitas pelayanan pada ketepatan dan kedatangan mobil. Kemudahan mendapatkan tiket bagi pelanggan yang akan 
mengsunakan jasa transportasinya Meningkatkan dedikas; para pegawai dalam bekerja Panshote amanan untuk para polanggar se: penteran asuransi untuk menunjukkan pids pelangsan bahwa perusahaan mempuryai komitmen pada keselamatan pelanggan.

3. Penelitian ini hanya dilihat dari sudut pandang pelanggan saja, maka untuk penelitian selanjutnya diharapkan meneliti kualitas pelayanan dengan membandingkan tingkat kualitas pelayanan yang diberikan pihak perusahaan dengan tingkat kualitas layanan yang diterima pelanggan.

\section{Keterbatasan Penelitian}

Penelitian ini menganalisis pengaruh Total Service Quaiity Management terhadap kepuasan pelanggan, sehingga penilaian tingkat kualitas pelayanan yang diberikan oleh perusahaan hanya dilihat dari sudut pandang pelanggan saja, maka penelitian selanjutnya diharapkan meneliti kualitas pelayanan dengan membandingkan tingkat kualitas pelayanan yang diberikan pihak perusahaan dengan tingkat kualitas layanan yang diterima pelanggan, berdasarkan tingkat kepuasan yang diterima. Penelitian diharapkan juga dilakukan pada semua semua jurusan/trayek yang dilayani oleh perusahaan travel.

\section{DAFTAR PUSTAKA}

Fandy Tj., 2005, Pemasaran Iasa, Edisi 1, Cetakan Pertama, Penerbit Bayumedia, Malang, Jawa Timur.

Fandy Tj,\& Anastasia D., 2000, Tota! Quality Management (edisi revisi), ANDI, Yogyakarta.

Fitzsimmons, JA \& Fitzsimmons, MJ, Service Management, Sixth Edition, McGraw Hill International Edition, New York.

Hartono, 2004, Statistik Untuk Penelitian, LSFK2P, Yogyakarta.

Heizer, J. \& Render, B, Operations Management, Ninth Edition, Prentice Hall, New Jersey.

Kotler, P.,\& Susanto A.B., 1999, Manajemen Pemasaran di Indonesia, Salemba empat, Jakarta.

Mudrajad K., 2003, Metode Riset untuk Bisnis \& Ekonomi (bagaimana meneliti \& menulis tesis?). Erlangga, Jakarta.

Mulyadi, 1998, Total Quality Management Prinsip Manajemen Kontemporer untuk Mengarungi Lingkungan Bisnis Global), Aditya Media. Yogyakarta.

Munjiati M 2003, Míanajemen Kualitas, UPFE UMY, Yogyakarta.
Murdifin H., 2005, Studi Pengaruh Berbagai Soft Element dalam TQM terhadap Berbogai Dimensi Mutu Keluarar Manufaci. Usahawan No.3.

Said Dj., 2004, TQM VIS-A-VIS TSOM IYSTEM. JMT STMT, Trisakti, Jakaria.

Supratno J., 2001, Pengukuran Tingkat Kepuasan Pelanggan (edisi baru), RINEKA CIPTA, Jakarta. 